\title{
Paleodepositional Environment and Sequence Stratigraphy of Miocene Sediments in Well TN-1, Coastal Swamp Depobelt, Niger Delta Basin, Nigeria
}

\author{
Jerry Osokpor $^{1^{*}}$ and Efetobore G Maju-Oyovwikowhe ${ }^{2}$ \\ ${ }^{1}$ Department of Earth Sciences, Federal University of Petroleum Resources, PMB 1221, \\ Effurun, Delta State, Nigeria \\ ${ }^{2}$ Department of Geology, University of Benin, PMB 1154, Benin City, Edo State, Nigeria \\ Efetobore.maju@uniben.edu \\ *Corresponding author, e-mail: osokpor.jerry@fupre.edu.ng
}

Received 23 July 2021, Revised 18 Oct 2021, Accepted 23 Oct 2021, Published Dec 2021

DOI: https://dx.doi.org/10.4314/tjs.v47i5.4

\begin{abstract}
This research focused on the interpretation of paleodepositional environment and development of a sequence stratigraphic framework for the well $\mathrm{TN}-1$ section, located in the coastal swamp depositional belt of the Niger Delta Basin. Integration of interpreted litho- and biofacies data sets that facilitated the interpretation of the paleodepositional environment enabled the erection of a sequence-stratigraphic framework. Three lithotypes (sand, clay, and shale) distributed within fourteen facies variants were integrated with palynomorph components to delineate five paleodepositional cycles ranging from distal delta plain to bathyal. Eight systems tracts (closely related to depositional cycles, but transcended depositional boundaries in some intervals) that hosted three maximum flooding surfaces (MFS), three sequence boundaries (SBs), distributed within four third-order and three second-order sequences, were defined. Age-significant palynomorphs recovered indicated an Aquitanian to Messinian age range (with non-deposition or erosion of Burdigalian, Langhian, Serravallian Stages sediments), distributed within five pollen zones (P628-P840) that correlated with published global cycles. This study demonstrates the significance of integrated studies to erect a sequence-stratigraphic framework applicable for field and basin-scale exploration and exploitation purposes.
\end{abstract}

Keywords: Sequence stratigraphy, paleodepositional cycles, systems tract, cyclic sedimentation, lithofacies analysis, integrated studies.

\section{Introduction}

The drive to define and unravel the paleodepositional settings in which sediments formed in petroliferous basins has been of great interest to the sedimentary and petroleum geologist communities since it provides a basis for predicting gross sedimentary characteristics, sand body geometry, and architecture of petroleum reservoirs. The sediments of the Niger Delta Basin generally are deposited in continental and marine environments as two broad geologic settings (Short and Stauble 1967,
Avbovbo 1978, Whiteman 1982, Doust and Omatsola 1990). However, the subenvironments in which the sediments were formed must be well defined because the ultimate fine detail of the deposit formed is a function of the sub-environment. Various pieces of evidence are employed to unravel the gross environment of deposition. The pieces of evidence include the fine-scale detail presented by individual sediment grain, the micro- and macrofossils (Legler et al. 2013, Osokpor and Ogbe 2020, Ekwere and Osokpor 2020), geophysical logs (especially 
gamma-ray) trends (Ogbe 2020), geochemical proxies (Osokpor and Osokpor 2020, Overare et al. 2020), and mineralogy and, seismic reflection data sets (Ogbe 2020), etc. It is noteworthy that any number of these data types is important for a more robust and accurate interpretation. In many instances, the availability of these tools listed is practically not feasible, hence researchers often find it difficult to unravel paleodepositional systems in ancient sediments.

Defining depositional systems of sediments is of crucial importance since it provides a basis for predicting reservoir facies and potential petroleum source and seal facies. Facies definition in the context of the concepts is a fundamental tool to unravelling paleodepositional systems since it ultimately serves as an underlying tool for erecting sequence stratigraphic frameworks in sedimentary systems. The main objectives of the present study were to use both litho- and biostratigraphic characteristics of the sediments retrieved from well $\mathrm{TN}-1$ located in the coastal swamp depobelt of the Niger Delta to interpret the paleodepositional environments and erect a sequence stratigraphic framework useful for field-scale correlation in adjacent areas, as well as defining systems tracts useful for predicting sand quality, geometry and architecture and potential source and seal facies in the location and other parts of the basin.

\section{Geologic Framework of the Niger Delta Basin}

Cretaceous tectonics in the Benue Valley and synsedimentary tectonics controlled and shaped the evolution and development of the Niger Delta Basin (Evamy et al. 1978, Ejedawe 1981, Knox and Omatsola 1987, Stacher 1995). The delta is situated on the Atlantic coast on the trailing edge of the African plate around the site of the Cretaceous triple junction. The geographic extent of the Niger Delta indicated by latitudes $4^{\circ}$ and $6^{\circ} \mathrm{N}$ and longitudes $3^{\circ}$ and $9^{\circ}$

$\mathrm{E}$ defines its boundaries (Figure 1). Regressive sedimentation that was climatedriven and proximity to provenance, controlled a north-south progradation that initially commenced as distinct lobes but later coalesced to form the present delta fill (Reijers 2011). The regressive phase of the delta that began in the Eocene has built out over the African continental fringe and contiguous oceanic crust since this period and continues to Recent (Evamy et al. 1978). The delta has developed due to rapid sedimentation into five megastructural units: Northern Delta; Greater Ughelli; Central Swamp; Coastal Swamp; and Offshore depositional belts. These units indicate sites for the most active sedimentation in the delta through time (Doust and Omatsola 1990, Tuttle et al. 1999, Saugy and Eyer 2003, Reijers 2011).

The development of the Niger Delta Basin is closely associated with the opening of the Gulf of Guinea in the Early Cretaceous linked to the origin of the South Atlantic when the South American and the African Plates drifted apart. This tectonic event created a ridgeridge-ridge (R-R-R) triple junction (rifting) during the Early Albian (112 Ma) that persisted to the Late Albian (ca. $107 \mathrm{Ma}$ (Reyment 1965, Short and Stauble 1967, Burke et al. 1971, Murat 1972, Lehner and De Ruiter 1977, Wright 1981, Saugy and Eyer 2003). While two arms of this junction developed as active rifts into the Atlantic continental margins of Nigeria and Cameroon, the Benue Trough failed as the third arm. Three depositional cycles have formed in southern Nigeria basins (Short and Stauble 1967, Whiteman 1982). The first cycle is pre-Albian, characterized by marine sequences deposited during an initial marine incursion that reached up to the northern aspects of the Benue Trough and that terminated during the Santonian orogenic disturbances. The Campanian marked the beginning of the second cycle, during which the proto-Niger Delta was formed north of Onitsha with a transgression in the Paleocene (Whiteman 1982). The Paleocene Transgression commenced in the Late Maastrichtian and transcended the Cretaceous-Cenozoic boundary, and terminated in the Ypresian (Evamy et al. 1978). Southward progradation of the Cenozoic deltaic sediments during the Early 
Eocene has continued to the present and marks the third cycle of sedimentation in southern Nigeria. The progradation characterized by an influx of sediment transported by the extensive Niger-Benue River drainage systems with sources in the Guinea Highlands and the Cameroon Mountains east of the Nigeria-Cameroon borders through the Cretaceous Anambra Basin and the insignificant Calabar drainage system through the Afikpo Basin (Short and Stauble 1967, Evamy et al. 1978, Whiteman 1982). Less-significant drainage systems such as the River Ethiope and Imo Rives (Ogbe 2020), the Warri and Qua-Ibo Rivers in the western and eastern parts of the basin individually are also making inputs to the growth of the progressing delta in Recent times (Figure 1).

The Niger Delta displays a three-fold stratigraphic division; the Akata Formation (bottom set), Agbada Formation (foreset) and the Benin Formation (top set) that reflect the main depositional settings. The Akata Formation consists of parallel-laminated marine shale formed in deep water basin-floor settings and constitutes the pro-delta sequence conventionally regarded as the main source rocks of the hydrocarbon resources in the Niger Delta Basin. It is over-pressured due to poor dewatering and rapid sedimentation of the overlying Agbada Formation. The Akata Formation is about 3-4 km thick (Doust 1989, Haack et al. 2000). A major regional sequence boundary between the Akata and Agbada Formations marks an abrupt change in the depositional environment (Morgan 2003). The Agbada Formation has a thickness of over 3 $\mathrm{km}$ and unconformably overlies the Akata Formation. It consists of mixed clastic sediments formed initially as distinct fan lobes in paralic settings but later amalgamated into a single prograding delta wedge (Figure 2 ). The Benin Formation consists of poorly sorted quarts arenite and subarkosic arenite of largely continental fluvial origin (Short and Stauble 1967, Avbovbo 1978, Whiteman 1982). The three formations were deposited in various depositional settings and displays diachronous age. The Akata Formation was accumulated in the deep marine environment and has an age range of Eocene to Recent. The Agbada Formation accumulated in a paralic environment and has an age range of Oligocene to Recent, while the Benin Formation deposited in fluvial delta plain environment and range from Oligocene to Recent in age (Short and Stauble 1967)

Large-scale synsedimentary diastrophic features such as growth faults and associated rollover anticlines and shale diapirs, initiated by shale tectonics and related to different stages of delta growth, characterize subsurface formations of the Niger Delta Basin (Short and Stauble 1967, Evamy et al. 1978, Whiteman 1982, Doust and Omatsola, 1990).

\section{Previous palynological studies in the Niger Delta Basin}

Several palynostratigraphic studies have been conduction in the Niger Delta with the aim of providing information on the age range of the sediments, constraining paleodepositional conditions, source sediment maturation, paleo-vegetation and paleoclimatic studies, etc. Foremost amongst these studies include works by Van Hoeken-Klinkenberge (1966) on pollen and spores of Maastrichtian to Eocene age from Nigeria and works by Clarke (1966) and Clarke and Frederiksen (1968) on the systematics of new sporomorphs of Neogene of Nigeria. Germeraad et al. (1968) carried out extensive palynological studies on tropical palynomorphs of Cenozoic age with a focus on the Niger Delta Basin. Studies on the systematics and age determination of palynomorphs species recovered from Late Paleogene and Neogene sediments in the Niger Delta were done by Legoux (1978), Jan du Chêne and Salami (1978) and Oloto (1992), Ola and Adewole (2014), Osokpor et al. (2015). Other studies in the Niger Delta involving the applications of palynology in paleoclimate changes (Morley and Richards 1993, Bankole et al. 2014, Osokpor et al. 2019); high-resolution sequence stratigraphy (Armentrout et al. 1999); biosignals (Van der Zwan and Brugman 1999) and Paleodepositional environment and sequence stratigraphy (Oboh-Ikuenobe et al. 2005, Bankole et al. 2014, Osokpor and Ogbe 2017, 
Osokpor and Ogbe 2019, Ekwere and Osokpor 2020, Osokpor and Ogbe 2020). The application of pollen and spores in understanding of paleo-vegetational trends in the Niger Delta Basin was carried out by Ige (2009).

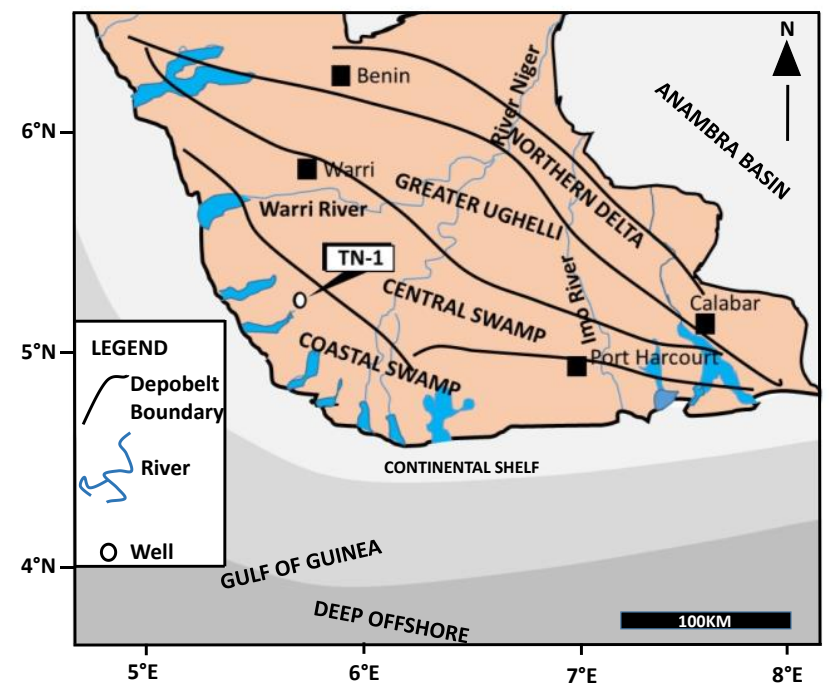

Figure 1: A simplified Niger Delta map showing its depositional belts and location of $\mathrm{TN}-1$ well. The Gulf of Guinea in the Equatorial Atlantic showing the continental shelf and deep offshore marine zones south of the onshore Niger Delta is shown (modified from Corredor et al. 2005).

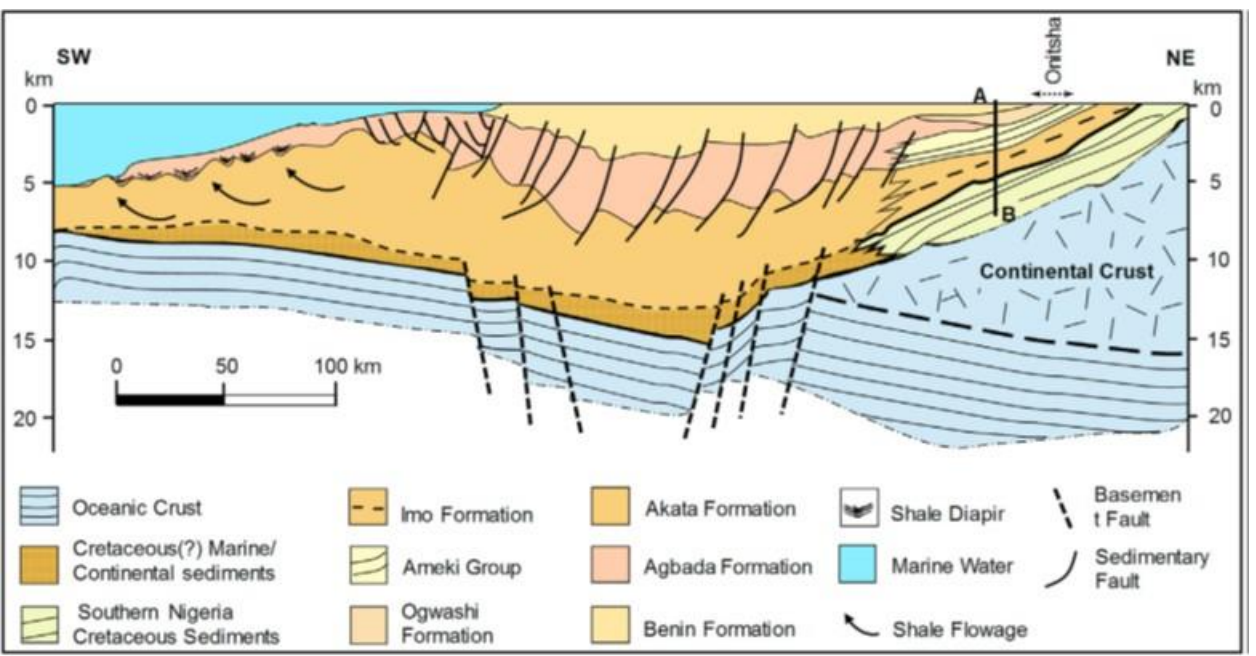

Figure 2: Regional Schematic northeast (NE)-southwest (SW) stratigraphic cross-section of the Cenozoic Niger Delta Basin showing the subsurface formations and their outcropping equivalents and underlying Cretaceous sediments of the Anambra Basin (Adapted from Ogbe and Osokpor 2020).

\section{Materials and Methods}

Detailed lithologic sample description of two hundred and twenty-two (222) noncomposited well-cutting samples from the well TN-1 in the Niger Delta Basin were subjected to whole-grain microscopic analysis. This was done to obtain information on grain size distribution, grain morphology, 
sorting, colour, the presence of accessory minerals and carbonaceous plant remains present in each sample, etc., by grain microscopy using a UNISCOPE SU 600096 reflected light microscope, to determine the whole-rock sedimentological characteristics.

Forty-two (42) shale samples were also selected and processed based on: facies characteristics, depth of resolution, intervals of interest, and confirmation of sedimentological results, to obtain palynomorph content. Standard palynological processing techniques described by Traverse (1988) were adopted for the sample analysis. The samples underwent various stages of acid treatment, sieving, density-separation, organic matter concentration by centrifugal method, staining with Safranin-O, and mounting on slides with Norland. The slides were finally covered with coverslips. Counting and speciation of palynoforms were done under transmission light microscope.

\section{Results and Discussions \\ Lithofacies analysis}

The synthesis of lithologic whole-grain characteristics obtained through grain microscopy provided information for the nomenclature of lithofacies. Four lithotypes: (sand, shale, silt, and clay); comprising thirteen lithofacies subdivisions (very finegrained sand, medium-grained sand, shaly very coarse sand, very coarse-grained sand, granules, shaly pebbly sand, pebbly sand, sandy clay, silt, sandy shale, silty shale, coaly shale, fissile shale) were defined as shown in Table 1 and Figure 3.

Table 1: Lithotypes and lithofacies recognized in well TN-1 section

\begin{tabular}{|c|c|c|c|}
\hline & & $\mathbf{A}$ & $\begin{array}{lll}\mathbf{C} & \mathbf{I} & \mathbf{E}\end{array}$ \\
\hline LITHOFACIES & FT & $\begin{array}{l}\text { Lithofacies } \\
\text { Name }\end{array}$ & Short description \\
\hline \multirow{7}{*}{ Sand } & 1 & $\begin{array}{l}\text { Very fine- } \\
\text { grained sand }\end{array}$ & $\begin{array}{l}\text { Very fine-medium-grained sand, sub<-subr., } \\
\text { contain shinny coaly materials, shaly, dark grey. }\end{array}$ \\
\hline & 2 & $\begin{array}{l}\text { Medium- } \\
\text { grained sand }\end{array}$ & Very fine-granular, subr-r, black shale component. \\
\hline & 3 & $\begin{array}{l}\text { Shaly very } \\
\text { coarse sand }\end{array}$ & $\begin{array}{l}\text { Very fine-granular, sub< - subr, black shale } \\
\text { component poor-verry poorly sorted. }\end{array}$ \\
\hline & 4 & $\begin{array}{l}\text { Very coarse } \\
\text { sand }\end{array}$ & $\begin{array}{l}\text { Very fine-pebbly, subr-wr, very fine and pebbly } \\
\text { grains occur as subordinate population, poor - well } \\
\text { sorted. }\end{array}$ \\
\hline & 5 & Granules & Medium-granular, subr-r, poorly sorted. \\
\hline & 6 & $\begin{array}{l}\text { Shaly pebbly } \\
\text { sand }\end{array}$ & Medium-pebble sized grains, poorly sorted. \\
\hline & 7 & Pebbly sand & Very fine-pebbly, subr-wr, well sorted. \\
\hline Clay & 8 & Sandy Clay & $\begin{array}{l}\text { Very fine sand component, shelly (bivalves), } \\
\text { brownish grey. }\end{array}$ \\
\hline Silt & 9 & Silt & Very fine, dark grey. \\
\hline \multirow{4}{*}{ Shale } & 10 & Sandy Shale & $\begin{array}{l}\text { Very fine-granular, silty and } \mathrm{CaCO}_{3} \text { in some } \\
\text { sections, light to dark grey, carbonaceous material. }\end{array}$ \\
\hline & 11 & Silty Shale & Silty, flaky, medium-dark grey. \\
\hline & 12 & Coaly Shale & Coaly and silty. \\
\hline & 13 & Fissile Shale & $\begin{array}{l}\text { Fissile, with subordinate silt component, woody } \\
\text { and carbonaceous material, medium-dark grey. }\end{array}$ \\
\hline
\end{tabular}

$F T=$ Facies type, Sub<: subangular, subr: subrounded, wr: well rounded, $r:$ rounded . 


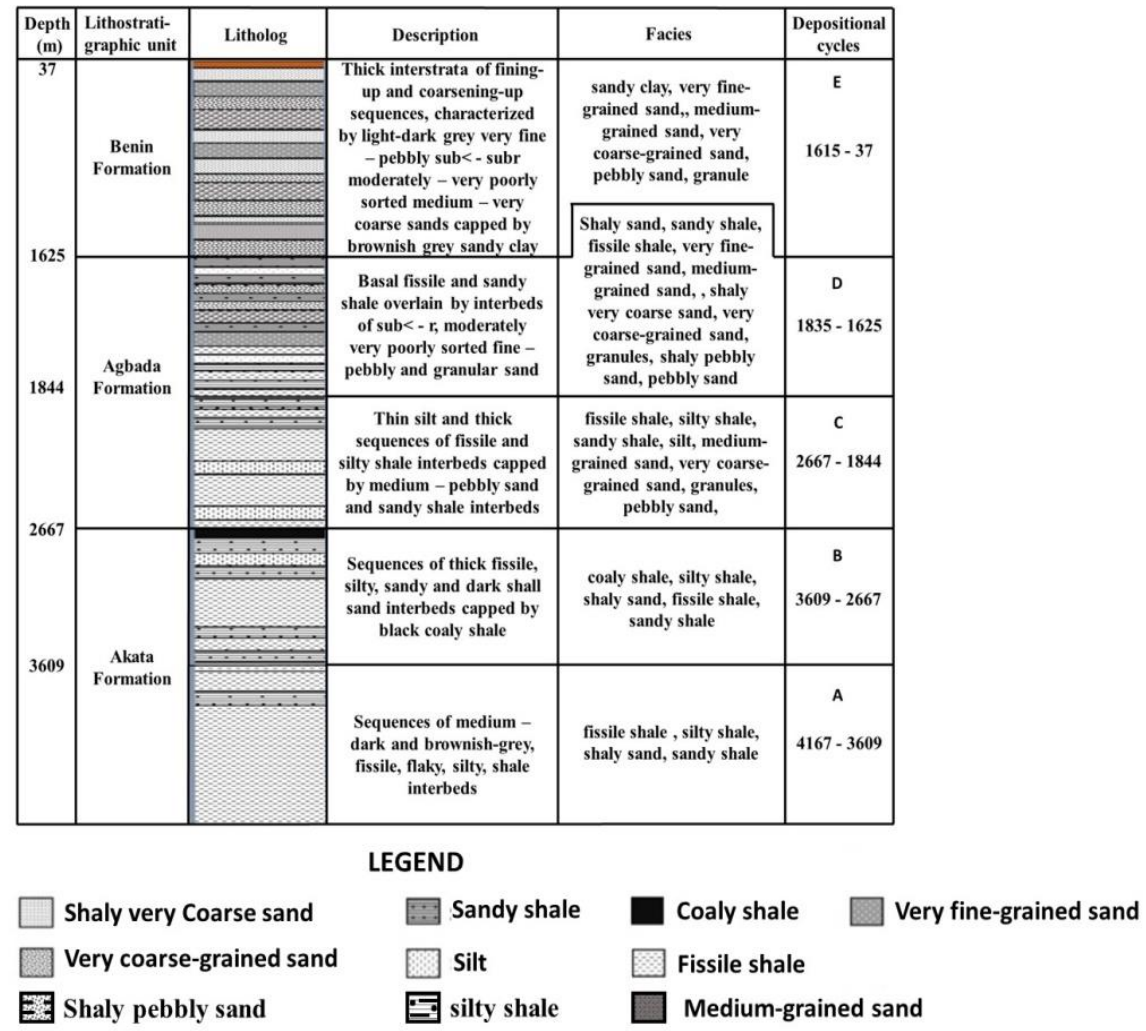

Figure 3: Lithologic log of the well section with summary lithologic description, facies, depth range of gross depositional cycles and lithostratigraphic units.

\section{Palynomorphs}

Palynomorphs recovered from the sediments were speciated as form species into miospores (pollen and spores) and dinocysts species (marine species). These palynomorphs formed the basis for the precise identification and quantification of species. Speciation of agesignificant forms enabled age calibration of the sediment profile. The sediment yielded eighty-seven (87) pollen, twenty-three (23) spores, and five (5) dinocyst form species. Figures 4 and 5 show quantitative distribution and ranges of the extracted palynomorph species. 


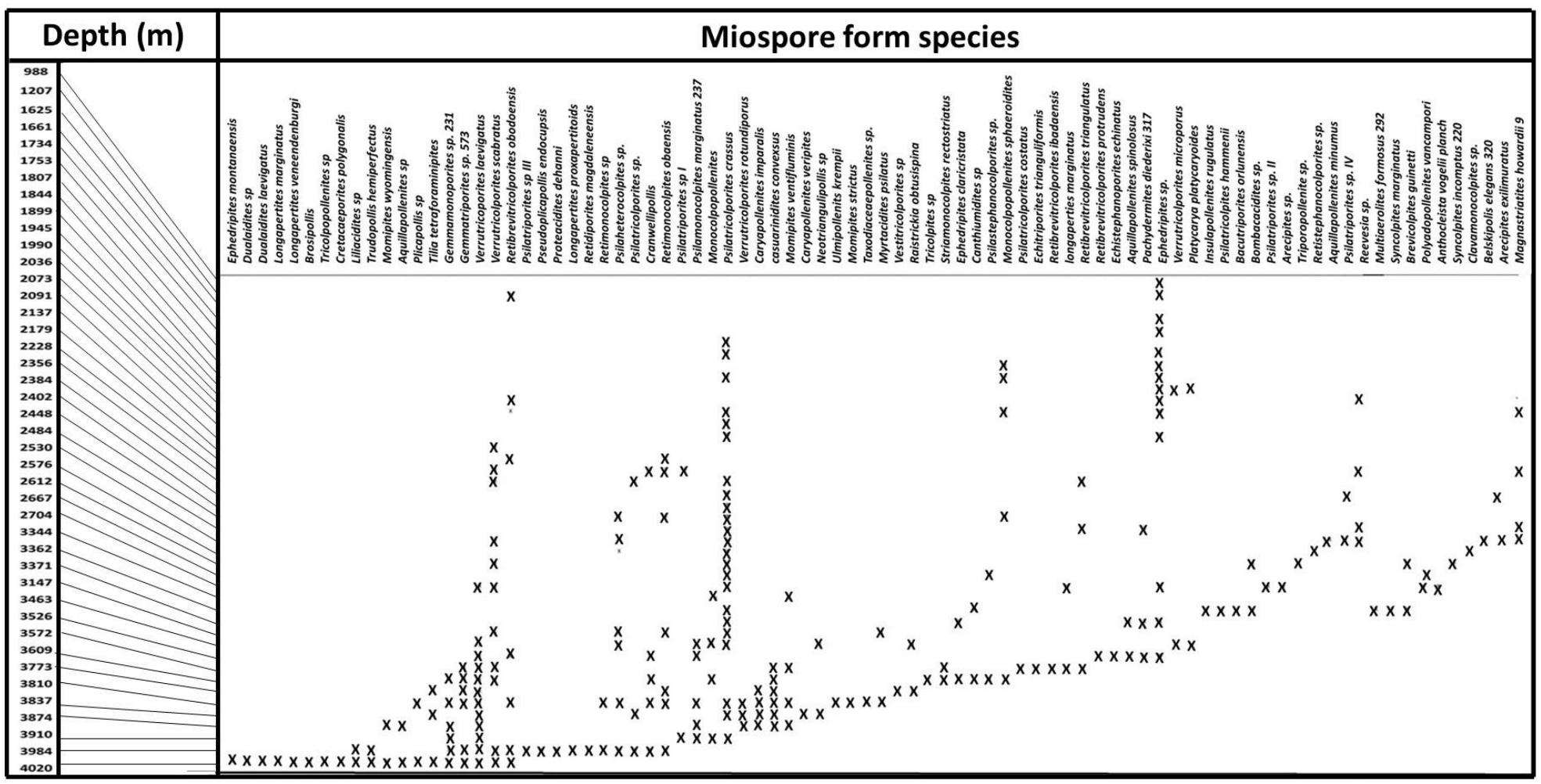

Figure 4: Depth occurrences and distributions of identified pollen species in well TN-1. 


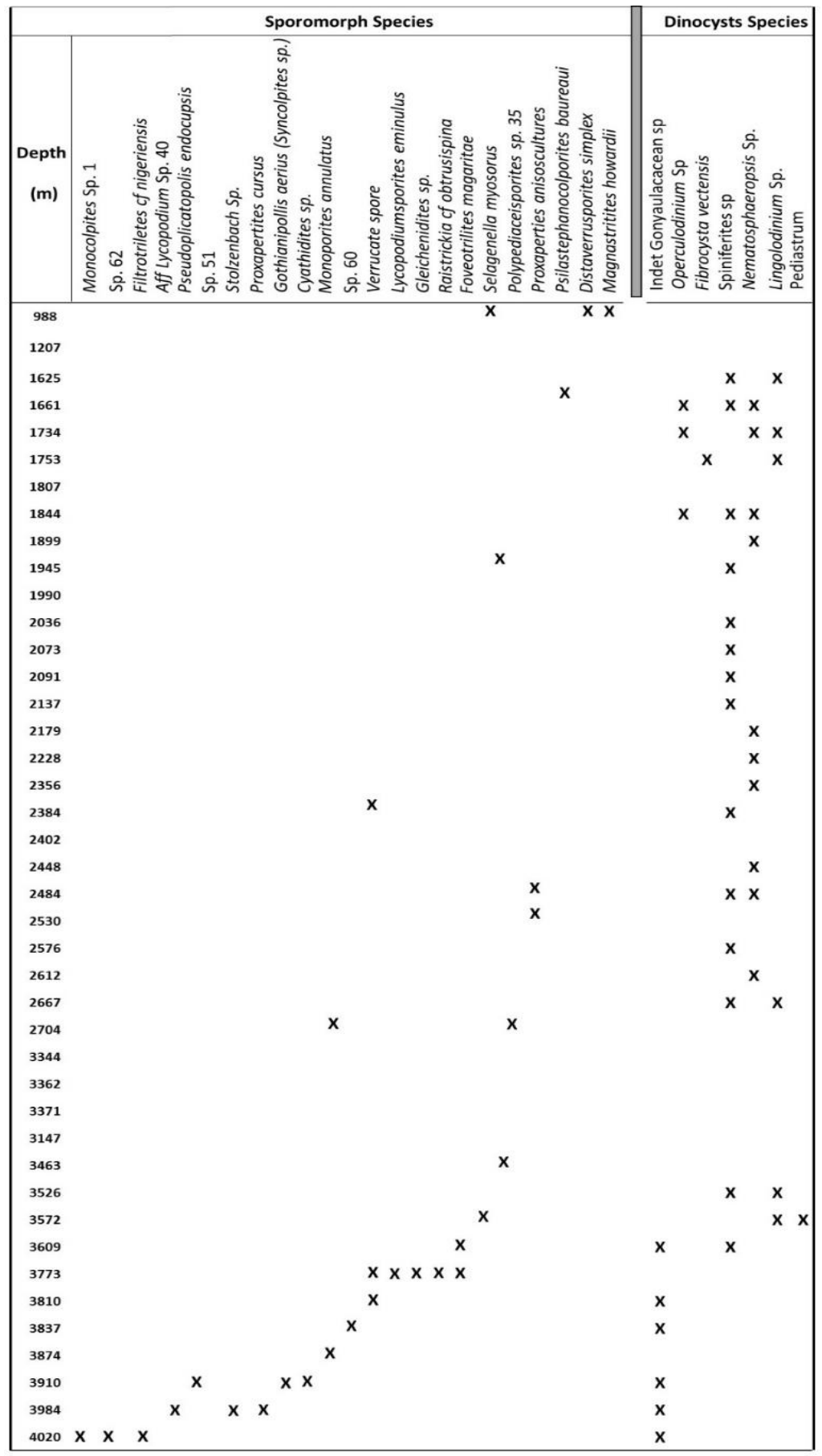

Figure 5: Depth occurrences and distributions of some identified sporomorph and dinocyst species recovered from well $\mathrm{TN}-1$.

\section{Paleodepositional environment}

Gross lithologic and biofacies signatures suggests paleodepositional environment systems in the sediments range from delta plain to deep marine environments that have been delineated into five paleodepositional 
cycles, A-E (cycles A and B in the Akata Formation, cycles C and D Agbada Formation and cycle $\mathrm{E}$ in the Benin Formation), based on gross lithologic and biofacies signatures. Lithologic and biofacies interpretations signalled a changing paleo-sea level as the driver of cyclicity in the investigated sediment profile. Sediments within 4167$3609 \mathrm{~m}$ depth (i.e., cycle A), occupying the lower section of the well (Figure 6), consists of flaky, dark brownish-grey fine shale at the basal aspects and alternating beds of silty shale, sandy shale, and fissile shale lithofacies at the mid to upper sections. This section has been dated Aquitanian (Osokpor 2013). The synthesis of an indeterminate gonyaulacacean dinocyst species and the gross sedimentologic characteristics of the sediment is suggestive of deposition in an open marine or bathyal paleodepositional setting.

Interbeds at the depth range 3609-2667 m (cycle B) consists of silty dark grey micaceous shale units at the base and interbeds of dark fissile and sandy shale capped by black coaly shale at the upper section. The upper section yielded Spiniferites sp., Lingolodinium sp., Pediastrum sp., and indeterminate species of gonyaulacacean cysts and capped by black coaly shale. Integrated lithofacies and biosignal results indicate cyclic deposition in paralic-bathyal paleodepositional settings. Cycle B ranges from Aquitanian-Tortonian Stage.

Sediments at the depth interval 2667-1844 m (cycle C) (Figure 6) are, characterized by interbeds of fissile and silty shale, and thin silt interbeds at the base, overlain by shaly sand and fissile shale interbeds, is characterized by shiny coaly material and numerous lightcoloured mica flakes. The shale interval deposited on the basal section yielded, Nematosphaeropsis labyrinthea, a deep marine gonyaulacacean species, while samples from the upper interval yield Spiniferites sp. The coupling of the lithofacies and biosignal characteristics indicated deposition in shallow to deep marine paleobathymetric settings during the Tortonian Stage.

The depth interval of 1844-1615 m which is of Tortonian-Messinian age (cycle D) (Figure 6), is composed of thick sequences of fissile and sandy shale lithofacies that yielded Nematosphaeropsis labyrinthea at basal section and Operculodinium centrocarpum at mid-section, both species are suggestive of bathyal depth. Single occurrences of Spiniferites sp., Lingolodinium sp., and Fibrocysta vectensis, all shallow marine species, were recorded at the mid-section. The upper section of the interval is dominated by beds of various sand facies interbedded with the shale facies. Further miospore evaluation shows a subordinate fungi spore population trend and total pollen species higher than spore counts. A synthesis of the above characteristics indicates deposition in shallow to deep marine, possibly middle neritic to bathyal paleobathymetric zones.

Cycle E occupies the depth range of $1615-37 \mathrm{~m}$ and is of Late MiocenePliocene? (Figure 6). This interval consists of very poorly sorted, very coarse-grained sand lithofacies at the base, is overlain by interbeds of fine-, medium-, coarse-grained, very coarse, and pebbly sand lithofacies, capped by brownish grey sandy clay, that yielded centimetre-scale freshwater pelycepod shells. Paleoenvironmental inference based on the above characteristics points to deposition in fluvial channel (1615-73 m) and channel overbank (top section) within the delta plain settings. 


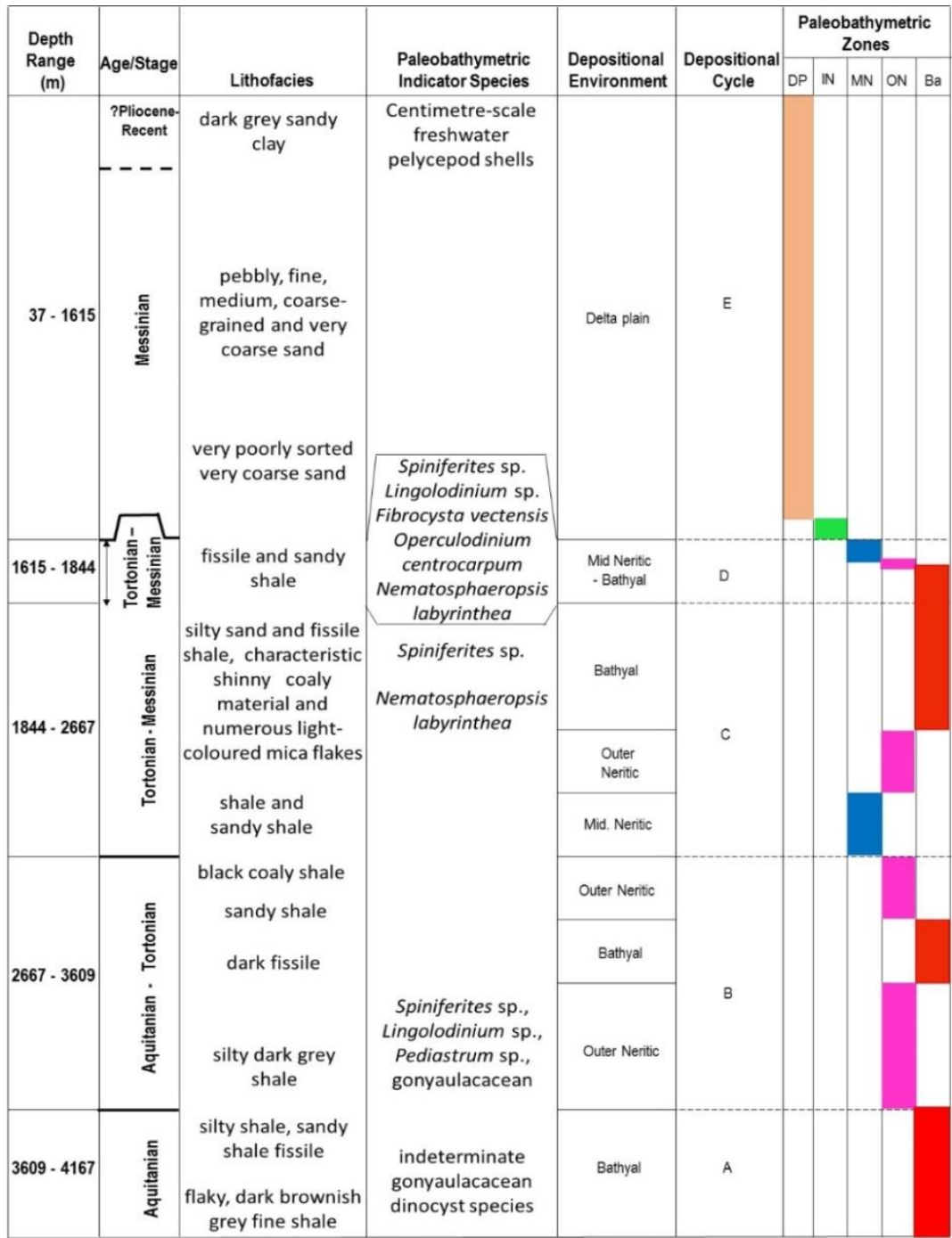

DP: Delta Plain, IN: Inner Neritic, MN: Middle Neritic, ON: Outer Neritic, Ba: Bathyal

- - - Approximate age boundary

Figure 6: Delineated paleobathymetric zones distributed within the five depositional cycles with their characteristic lithofacies and biofacies components. Note the gross depositional environment (GDE) ranges from delta plain to deep marine.

\section{Sequence Stratigraphy}

Sequences and systems tracts

Eight systems tracts that hosted three maximum flooding surfaces (MFS), three sequence boundaries (SBs), distributed within four third-order and three second-order sequences, have been defined and established in the well. Systems tracts were observed to be closely related to depositional cycles but transcended depositional boundaries. The third-order sequences range from 4020-3362 $\mathrm{m}$ (sequence 1), 3353-1734 m (sequence 2), and $1725-1625 \mathrm{~m}$ (sequence 3 ), and 1615-37 m (sequence 4) (Figure 7). 


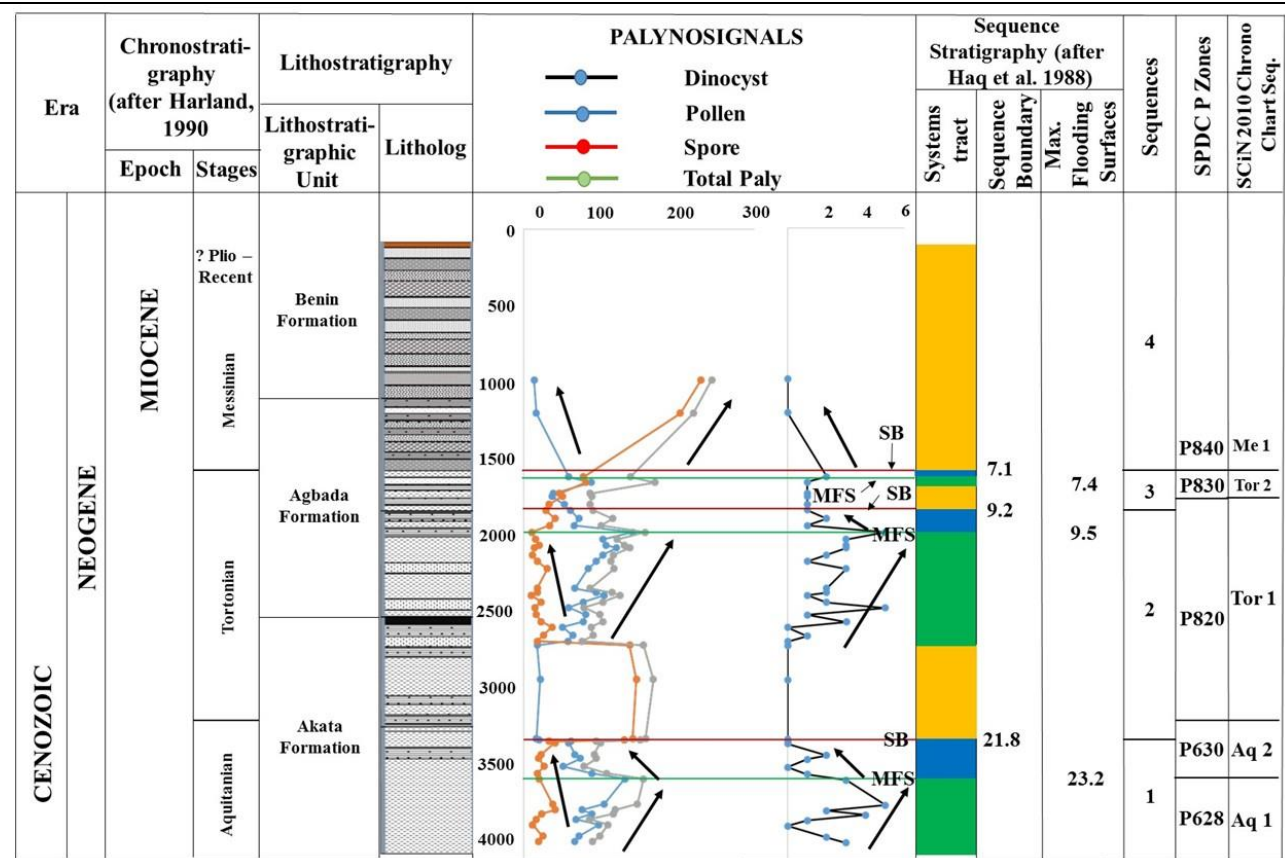

Figure 7: Quantitative depth plots of palynosignals and associated sequence stratigraphic elements, Niger Delta pollen zone and SCiN 2010 chronostratigraphic chart correlated with lithostratigraphic units and age in the well TN-1.

Lowstand systems tracts (LST): Three lowstand systems tracts ranged from 3353$2740 \mathrm{~m}$ (LST-1), 1725-1670 m (LST-2), to 1615-37 m (LST-3) (Figure 8), were identified in the sediment section. LST-1 commenced from the $21.8 \mathrm{Ma}$ sequence boundary (SB) dated Late Aquitanian stage (Aq 2) at a depth of $3353 \mathrm{~m}$ (Figures 7 and 8) and correlates with Evamy et al. (1978) P630 zone. LST-2 starts from the 9.6 Ma SB that marks the boundary between sequences 2 and 3 and of the Late Early Tortonian Stage (Tor 1) defined at a depth of $1725 \mathrm{~m}$ (Figure 8). The third LST-3 commenced at the 7.1 Ma SB at a base depth of $1661 \mathrm{~m}$ which marks the Tortonian-Messinian Stage boundary (Figure 8). A synthesis of lithofacies, palynosignals, and stacking patterns (generally progradational) indicated sedimentation in bathyal to neritic paleobathymetric domains within the three LST.

\section{Low stand systems tract palynosignals}

LST-1 -This interval recorded a dominance of open vegetation and subordinate rainforest vegetation-derived miospore species, which indicates a dry and cool climate that may have driven a fall in relative sea level. A synthesis of this biosignal attribute and the lithofacies characteristics signify a lowstand systems tract (LST) in a deep marine setting formed during the Aquitanian-Burdigalian transition in this location. This falling stage probably eroded Burdigalian, Langhian, and Serravillian Stages sediment noticed to be absent in the sediment section.

LST 2-This interval displays a dominance of savanna palynomorph assemblage such as Stereisporites sp., Laevigatosporites sp., Racemonocolpites hians, Retitricolporites sp., Gemmatricolpites sp. and several indeterminate forms.

LST 3-This interval displays abundant Laevigotosporites species, Elaeis guineensis, and several savanna species such as Arecipites sp., Graminae pollens, and numerous indeterminate trilete spores that implied dry and cool climatic condition at this stage. 


\section{Transgressive systems tract (TST)}

Three transgressive systems tracts (TSTs) were delineated in the well. These ranged from 4020-3609 m (TST-1), 2740-1972 m, and 1661-1643 m, capped by three maximum flooding surfaces (MFS) (Figure 8). The delineation of the systems tracks is based on an overall lithofacies composition and a general display of retrogradational parasequence stacking pattern, the palynofacies composition, and trends showed a dominance of freshwater swamp and rain forest pollen species, subordinate spore, and high pollen percentage. An abundance of rainforest and freshwater swamp pollen species is an indication of luxuriant vegetation evolved by warm and wet tropical climates (Santos et al. 2017). Warm global paleoclimates are known to orchestrate polar ice cap melting, the corresponding rise in sea level, registered as transgression, and imprinted in the sedimentary record with a display of retrogradational stacking pattern trends (Osokpor and Ogbe 2019). These signatures, commonly, are recognized in the Niger Delta (Oboh-Ikuenobe et al. 2005, Osokpor 2013, Osokpor and Ogbe 2019, 2020) and in the Campos and Espírito Santo Basins in Brazil (Moreira and Carminatti 2004).

\section{Maximum flooding surfaces (MFS)}

Three MFS were age-dated in the well. The first MFS is the $23.2 \mathrm{Ma}$ surface (Early Aquitanian, Aq 1) (Figure 8), established at $3609 \mathrm{~m}$ and marks the lower section of the Verruticolporites laevigatus/ $V$. scabratus zone B of Osokpor (2013), and correlates with the Evamy et al. (1978) P628 zone in the Niger Delta Chronostratigraphic zonation (SCiN 2010). The second MFS is the 9.5 Ma surface of the Early Late Miocene defined at 1972 m. It marks the Early Tortonian Stage (Tor 1) (Figures 7 and 8) and coincides with the P820 zone of Evamy et al. (1978). The third MFS is the $7.4 \mathrm{Ma}$ surface established at $1643 \mathrm{~m}$ and marks the Late Tortonian Stage (Tor 2) (Figures 7 and 8). It falls within the 830-pollen zone of Evamy et al. (1978).

\section{Highstand systems tracts (HST)}

Three highstand systems tracts (HST) that range from 3609-3362 $\mathrm{m}$ (HST 1), 1972$1734 \mathrm{~m}$ (HST 2), and 1634-1625 $\mathrm{m}$ was recognized in this study. These intervals display recognizable sediment aggradational and progradational patterns that were delineated based on palyno-, lithofacies and stacking patterns. Reduced spore and increased pollen abundance are a general trend for the intervals. Rain and mangrove forest vegetation species (Laevigatosporites sp., $\quad$ Arecipites exilimuratus, Psilatricolporites, Spinizonocol pites echinatus), abundant Sporites verrucatus, and Verrucatosporites

usmensis, known to be produced by several tropical forest fern species characterized the interval. These forms have been correlated with increased sea levels since they indicate warm paleoclimatic conditions (Poumot 1989). Indeterminate gonyaulacacean marine planktic species seen at the basal section of HST-1 point to deposition in a deep paleobathymetric domain. The mid to upper interval recorded single occurrences of shallow marine species, Spiniferites sp., Lingolodinium sp. And Fibrocysta vectensis, and an influx of the freshwater species, Pediastrum, which also indicated freshwater incursion/influence, known to characterize sea level still stand phases. 


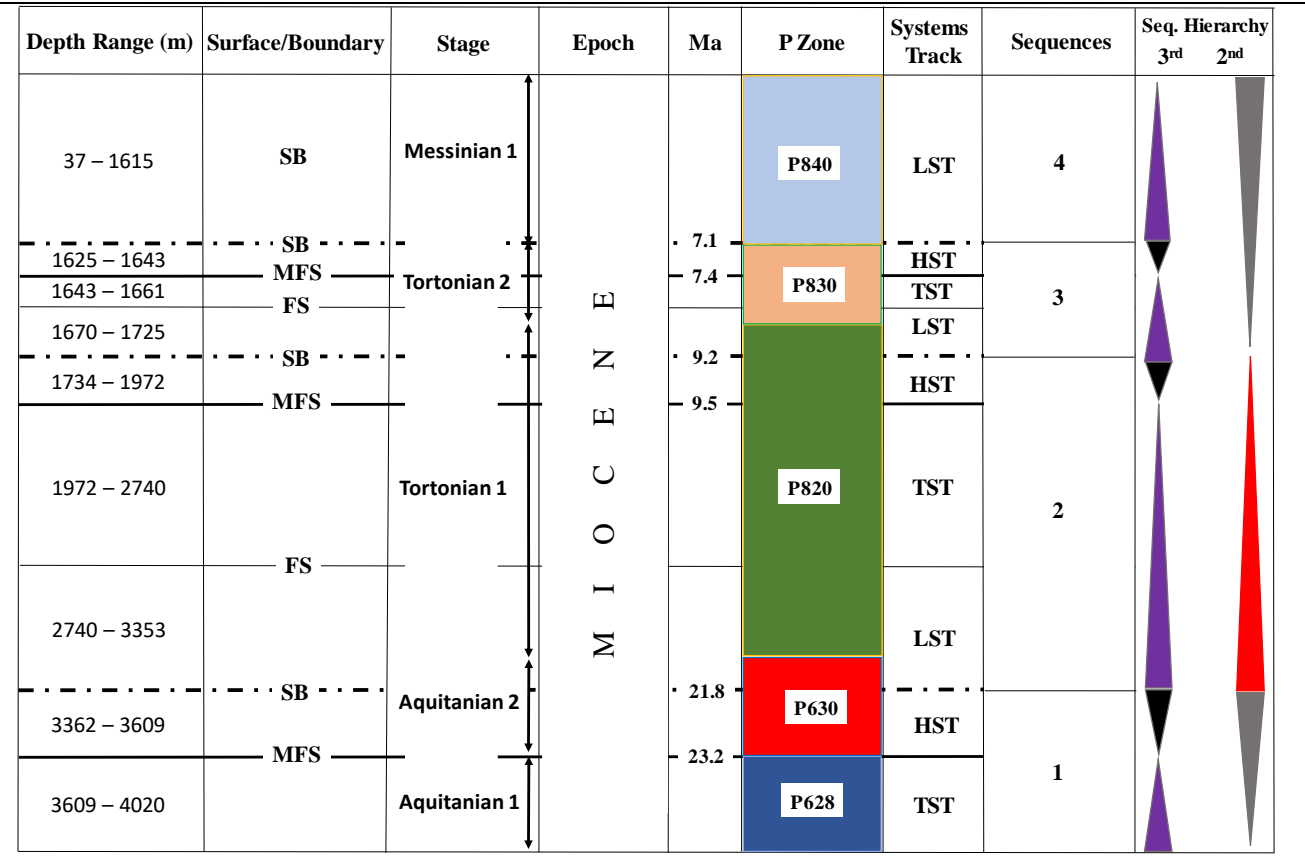

Figure 8: Sequence stratigraphic summary sheet showing systems tracts, major bounding surfaces, sequences, P-zones and sequence hierarchies. $C f$. Figure 7 for biosignal plot and sequence stratigraphic elements. FS- flooding surface, MFS- maximum flooding surface, LSTlowstand systems tract, HST- highstand systems tract, TST- transgressive systems tract, SBsequence boundary, Ma- million years, $\mathrm{P}$ zone- pollen zone, Seq.- sequence.

\section{Discussion}

The synthesis of paleoenvironmental proxies used in this study revealed that deposition occurred in a delta plain to deep marine settings for the sediments recovered from the well. The cyclic pattern of sedimentation displayed indicates a relationship with oscillatory sea level through time. The age of the section determined to be Miocene ranged from Aquitanian to Messinian stage and Pliocene to Recent for the uppermost section (Osokpor 2013) with the absence of Late lower to mid-Miocene age sediments. Based on lithofacies characteristics, the lower section of the well correlates with the Akata Shale Formation overlain by the Agbada Formation, while the uppermost section correlates with the Benin Formation.

The Miocene epoch in the area heralded a rising and transgressing sea that attained a maximum rise during the Early Aquitanian stage, indicated by the 23.2 Ma MFS, then reversed by a fall that created an erosional surface/boundary during the Late Aquitanian stage. The Burdigalian, Langhian, and Serravallian Stages sediments are absent in the well. The absence of three geological time stages is attributable to either erosion or a period of non-deposition in the sediment profile. Tortonian age sediments unconformably overlie Aquitanian age sediments, hence an Aquitanian-Tortonian transition separated by the 21.8 Ma sequence boundary. This boundary indicates an unconformity of about $11 \mathrm{Ma}$ in duration and overlain by low stand systems tract sediments, characteristic of cold climatic conditions. Several cut-and-fill events are present in the Niger Delta sedimentary fill. These sediments are the Oligo-Miocene (spanning ChattianLanghian) Opuama/Osare Channel complex fill in the western Niger Delta, the Seravillian Stage Agbada, Buguma, and the Soku channel fill in the eastern Niger Delta (Evamy et al. 1978). The erosional event noticed in this well may likely be related to the channelling listed above. Another sea-level rise 
characterized the Early Tortonian. This rise culminated in maximum flooding that formed the 9.5 Ma MFS in the Early Tortonian (Tor 1) (Figures 7 and 8). The Early Tortonian Sea rise event followed a short-lived falling sea level that created the 9.2 Ma SB. At the close of the Tortonian stage, sea level rise and fall occurred in rapid succession that generated the 7.4 Ma MFS and the 7.1 Ma SB (Tor 2). Quick succession of depositional cycles, as revealed by the palynosignals obtained for the well (Figure 7), indicate a rapid climate reversal.

The adoption of the maximum flooding surface in this study for defining the sequence boundary in the Niger Delta Basin is documented in Reijers (2011) and Osokpor and Ogbe (2019). Sequence stratigraphic studies by Osokpor and Ogbe (2019) on Cretaceous-Tertiary sediments from a well in the north-western area of the Niger Delta corroborated the position of Reijers (2011) on the application of the maximum flooding surface in defining sequence boundaries in the Niger Delta Basin. Albeit, these authors observed limitations on the use of erosional surfaces as sequence boundaries, maximum flooding surfaces in this study proved no advantage over erosional surfaces in erecting the sequence boundaries, thus erosional surfaces delineated in the well have been used as sequence boundaries instead of the maximum flooding surfaces. The observation poses a question: whether the model to be adopted is a function of the area concerned.

\section{Conclusions}

Integrated lithofacies and biofacies data provided a veritable tool for interpreting paleoenvironments of sediments retrieved from the well. The paleoenvironments defined in the well can be updated if additional environmental proxies are available. The sequence stratigraphic framework erected for the well provides a veritable tool for understanding depositional cyclicity in the sediment profile and suitable for predicting vertical and lateral facies changes and for local and basin-scale correlation.

The age-based sequence definition technique adopted for this work enabled the identification of missing sections due either to erosion or non-deposition that may be related to established erosional events in the Niger Delta Basin.

Declaration of interest statement: The authors declare no conflict of interest.

\section{Acknowledgements}

The authors specially acknowledge Prof. W.O. Emufurieta for providing the samples used for this study and Dr. F.A. Lucas for assistance in the identification of palynomorph taxa. Both of them are of the Geology Department, University of Benin.

\section{References}

Armentrout JM, Fearn LB, Rodgers K, Root S, Lyle WD, Herrick DC, Bloch RB, Snedden JW and Nwankwo B 1999 High-resolution sequence biostratigraphy of a lowstand prograding deltaic wedge: Oso field (Late Miocene), Nigeria. In: Jones RW, Simmons MD (Eds), Biostratigraphy in production and development geology, 152. Geol. Soc. London, Special Publications: 259-290.

Avbovbo AA 1978 Tertiary lithostratigraphy of Niger Delta. AAPG Bull. 62: 295-306.

Bankole SI, Schrank E and Osterloff LP 2014 Palynostratigraphy, palaeoclimates and palaeodepositional environments of the Miocene aged Agbada Formation in the Niger Delta, Nigeria. J. Afr. Earth Sci. 95: 41-62.

Burke K, Dessauvagie TFJ and Whiteman AJ 1971 Opening of the Gulf of Guinea and the geological history of the Benue Depression and Niger Delta. Nat. Phys. Sci. 233: 51-55.

Clarke RT 1966 Peregrinipollis nigericus, a new palynomorph from the Upper Tertiary of Nigeria. Grana Palynol. 6(3): 544-546.

Clarke RT and Frederiksen NO 1968 Some new sporomorphs from the Upper Tertiary of Nigeria. Grana Palynol. 8(1) 210-224.

Doust HE and Omatsola EM 1990 Niger Delta. In: Divergent/Passive Basins. Edwards JD and Santagrossi PA (eds). AAPG, Mem. 45: 201-238.

Doust H 1989 The Niger Delta: hydrocarbon potential of a major tertiary delta province: Proceedings, KNGMG Symposium "Coastal Lowlands, Geology and Geotechnology", 1987: Dordrecht, Kluwer, 203-212. 
Ejedawe JE 1981 Patterns of incidence of oil reserves in Niger Delta Basin. AAPG Bull. 65: 1574-1585.

Evamy DD, Haremboure J, Kamerling P, Knaap WA, Molloy FA and Rowlands PH 1978 Hydrocarbon habitat of Tertiary Niger Delta. AAPG Bull. 62: 1-39.

Ekwere UJ and Osokpor J 2020 Palynozonation and paleodepositional environment of Eocene-Oligocene sediment, northwestern Niger Delta Basin, Nigeria. Fed. Univ. Lafia J. Sci. Technol. 6(2): 11-19.

Germeraad JH, Hopping CA and Muller J 1968 Palynology of Tertiary sediments from tropical areas. Rev. Palaeobot. Palynol. 6: 189-348.

Haack RC, Sundararaman P, Diedjormahor JO, Xiao H, Gant NJ and May Kelsch ED 2000 Niger Delta petroleum systems, Nigeria. In: Mello, MR; Katz, BJ (Eds), Petroleum systems of South Atlantic margins. AAPG Bull. 73: 213-231.

Ige OE 2009 A late tertiary pollen record from Niger Delta, Nigeria. Int. J. Bot. 5(3): 203215.

Jan du Chêne RE and Salami MB 1978 Palynology and micropalaeontology of the Upper Eocene of the well Nsukwa 1 (Niger Delta, Nigeria). C. $r$. des Séances SPHN Gèneve, N.S. 13: 5-9.

Knox GJ and Omatsola ME 1987 Development of the Cenozoic Niger Delta in terms of the escalator regression model, in, Proceedings of the KNGMG Symposium 'Coastal Lowlands-Geology and Geotechnology. Kluwer Academic Publishers: 181-202.

Legler B, Johnson HD, Hampson GJ, Massart BYG, Jackson CAL, Jackson MD, ElBarkooky A and Ravnas R 2013 Facies model of a fine-grained, tide-dominated delta: lower Dir Abu Lifa Member (Eocene), Western Desert, Egypt. Sedimentol. 60: 1313-1356.

Legoux O 1978 Quelques espèces de pollen caractéristiques du Néogéne du Nigéria. Bull. Cent. Rech. Explor.-Prod. ElfAquitaine 2(2): 265-317.

Lehner P and De Ruiter PAC 1977 Structural history of Atlantic Margin of Africa: $A A P G$ Bull. 61: 961-981.

Moreira JLP and Carminatti M 2004 Eocene slope and basin depositional systems in the Santos Basin: Petrobras Geosci. Bull. 12(1): 73-87.
Morgan R 2003 Prospectivity in ultradeep water: The case for petroleum generation and migration within the outer parts of the Niger Delta apron. Geol. Soc. Spec. Publ. 207(1): 151-164.

Morley RJ and Richards K 1993 Gramineae cuticles: a key indicator of Late Cenozoic climatic change in the Niger Delta. Rev. Palaeobot. Palynol. 77: 119-127.

Murat RC 1972 Stratigraphy and paleogeography of Cretaceous and Lower Tertiary in Southern Nigeria, in, Dessauvagie TFJ, Whiteman AJ, eds, African Geology. University Ibadan Press, Nigeria. 221-266.

Oboh-Ikuenobe FE, Obo CG and Jaramillo CA 2005 Lithofacies, palynofacies and sequence stratigraphy of Palaeogene strata in southeastern Nigeria. J. Afr. Earth Sci. 41: 79101.

Ogbe OB 2020 Sequence stratigraphic controls on reservoir characterization and architectural analysis: A case study of Tovo field, coastal swamp depobelt, Niger Delta Basin, Nigeria. Mar. Pet. Geol. 121: 104579.

Ola PS and Adewale BK 2014 Palynostratigraphy and paleoclimate of the sequences penetrated by Meren 31 Side tract-2 Well, Offshore Niger Delta. Int. J. Geosci. 5: 1206-1218.

Oloto IN 1992 Succession of palynomorphs from the Early Eocene of Gbekebo-1 well in S.W., Nigeria. J. Afr. Earth Sci. 15: 441452.

Osokpor J 2013 Petroleum potentials, paleodepositional environment and sequence stratigraphy of cretaceous-tertiary sediments in parts of the Benin Flank and Niger Delta Basins. PhD thesis, University of Benin, Nigeria.

Osokpor J, Ekwere UJ, Otele A 2019 Paleoclimatic cycles, sea level history and sequence stratigraphic elements in EoceneOligocene sediments of BIMOL-1 Well Northern Niger Delta Basin, Nigeria. $J$. Appl. Sci. Environ. Manag. 23(2): 241-248.

Osokpor J, Lucas FA, Osokpor OJ Overare B and Izeze OE 2015 Palynozonation and lithofacies cycles of Paleogene to Neogene age sediments in PML-1 Well, northern Niger Delta Basin. Pacific J. Sci. Technol. 16(2): 286-297.

Osokpor J and Ogbe OB 2017 Facies evolution, paleodepositional environment and sequence 
stratigraphy of Tertiary sediments, northwestern Niger Delta Basin. Dev. J. Sci. Tech. Res. 6(2): 9-24.

Osokpor J and Ogbe OB 2020 Paleodepositional environment and reservoir biosequence stratigraphy of Late Paleogene-Neogene sediments from the KB-1 well, Coastal Swamp depobelt, Niger Delta Basin, Nigeria. Int. J. Sci. Eng. Res. 11(6): 17421770.

Osokpor J and Osokpor OJ 2020 Geochemical proxies from clays in parts of northern Niger Delta: implication for unravelling paleodepositional environment and paleoweathering. FULafia J. Sci. Tech. 6(2): 6-14.

Osokpor J and Ogbe OB 2019 Sequence stratigraphic signatures from Xen-1 Well: key for understanding Cretaceous-Tertiary transitional events in the North-western Niger Delta Basin, Nigeria. Pet. Coal 61(4): 860-880.

Overare B, Osokpor J, Ekeh PC and Azmy K 2020 Demystifying provenance signatures and paleo-depositional environment of mudrocks in parts of south-eastern Nigeria: constraints from geochemistry. J. Afr. Earth Sci. 172: 103954.

Poumot C 1989 Palynological evidence for eustatic events in the tropical Neogene. Bull. Centre Rech. Explor. Prod. Elf Aquitaine 13(2): 437-453.

Reijers TJA 2011 Stratigraphy and sedimentology of the Niger Delta. Geologos. 17(3): 133-162.

Reyment RA 1965 Aspects of the geology of Nigeria: The Stratigraphy of the Cretaceous and Cenozoic deposits. Ibadan University Press. $145 \mathrm{p}$.

Santos A, Carvalho MA, de Oliveira AD and Filho JGM 2017 Paleoenvironmental changes and influence on Operculodinium centrocarpum during the Quaternary in the Campos Basin, south-western Brazil. $J$. South Am. Earth Sci. 80: 255-271.

Saugy L and Eyer JA 2003 Fifty years of exploration in the Niger Delta (West Africa). In: Halbouty, MT (Ed) Giant Oil and Gas Fields of the Decade 1990-1999. AAPG Bull. 78: 211-226.

SCiN Chronochart 2010 International commission on stratigraphy.

Short KC and Stauble AJ 1967 Outline of the geology of Niger Delta. AAPG Bull. 51(5): 761-779.

Stacher P 1995 Present understanding of the Niger Delta hydrocarbon habitat, In: Oti MN, and Postma G (Eds), Geology of Deltas: Rotterdam, A.A. Balkema. 257-267.

Traverse A 1988 Palaeopalynology. Unwin Hyman, London. 1-600.

Tuttle MLW, Charpentier RR and Brownfield ME 1999 The Niger Delta petroleum system: Niger Delta Province, Nigeria, Cameroon, and Equatorial Guinea, Africa. US Geol. Surv. Open File Report. 99-50-H.: 65.

Van der Zwan CJ and Brugman WA 1999 Biosignals from the EA Field, Nigeria. In: Jones, RW, Simmons, MD (Eds.), Biostratigraphy in production and development geology, 152. Geol. Soc. London, Special Publications: 291-301.

Van Hoeken-Klinkenberge PMJ 1966 Maastrichtian, Paleocene and Eocene pollen and spores from Nigeria. Leidse. Geol. Meded. 38: 37-48.

Whiteman AJ 1982 Nigeria, its petroleum geology, resources, and potential ( $1^{\mathrm{st}} \mathrm{Edn}$.). Graham and Trotman Ltd. London.

Wright JB 1981 Review of the origin and evolution of the Benue Trough in Nigeria. Earth Evol. Sci. 2: 98-103. 